\title{
INFLUÊNCIA DE PROPRIEDADES DA GASOLINA EM PARÂMETROS DE DESEMPENHO DE MOTORES E VEÍCULOS
}

\author{
Guilherme Bastos Machado, Antonio Carlos Scardini Villela, Ana Carolina Bueno Bontorin, \\ Katia Moniz da Silva, Sergio William Botero
}

Petróleo Brasileiro S.A. - Petrobras / CENPES

E-mails: machadogb@petrobras.com.br; antonio.villela@petrobras.com.br; ana.bontorin@petrobras.com.br; kmsilva@petrobras.com.br; sergio.botero@petrobras.com.br

\section{RESUMO}

No mercado de combustíveis automotivos para veículos leves do ciclo Otto há variações naturais das propriedades físico-químicas das gasolinas, tais como poder calorífico, massa específica, relação ar-combustível estequiométrica, octanagem, entre outras. Investigar a influência dessa variação de propriedades nos parâmetros de desempenho dos motores e veículos é importante. Dentro deste contexto, foi realizada avaliação de desempenho e consumo de combustível, utilizando gasolinas de diferentes procedências, em motores e veículos de tecnologias GDI (gasoline direct injection) e PFI (port fuel injection). Os ensaios foram realizados em banco de provas de motor e dinamômetro de chassi. Os resultados mostram que as propriedades das gasolinas podem influenciar de forma diversa o desempenho e o consumo de combustível mássico e volumétrico, a depender da tecnologia e da estratégia de calibração dos motores e veículos. Evidencia-se a importância do desenvolvimento de sistemas de controle do motor mais sensíveis às variações dos combustíveis, para minimizar a influência no desempenho e eficiência.

\section{INTRODUÇÃO}

As variações de propriedades da gasolina podem influenciar os parâmetros de desempenho dos motores e veículos de várias maneiras. A octanagem, por exemplo, está diretamente relacionada com a potência desenvolvida, a depender do projeto do motor, da calibração e sensibilidade do sistema de controle do motor. Por sua vez, poder calorífico, relação arcombustível estequiométrica e massa específica têm influência mais direta no consumo de combustível. Na prática, ocorre uma influência combinada das propriedades do combustível nos parâmetros de desempenho dos motores e veículos com impactos na eficiência energética, que podem variar em função da tecnologia dos motores.

Nos últimos anos houve um aumento da participação de gasolinas importadas no mercado nacional[1]. A partir de 2016, com a adoção pela Petrobras da política de preços que tem como base a paridade com o mercado internacional, houve um aumento expressivo das importações chegando a $450.000 \mathrm{~m}^{3}$ em fevereiro de 2018. Essas gasolinas, em geral, apresentam massas específicas mais baixas em relação às gasolinas produzidas no Brasil. 
Verifica-se que entre janeiro e dezembro de 2017, a média das massas específicas de todos os tanques de gasolina A produzidos na Petrobras foi de $728,1 \mathrm{~kg} / \mathrm{m}^{3}$. Neste período, apenas 1,3 $\%$ dos tanques de gasolina A liberados apresentaram massa específica abaixo de $710,0 \mathrm{~kg} / \mathrm{m}^{3}$. Ao mesmo tempo, algumas gasolinas importadas apresentaram massas específicas abaixo de $690,0 \mathrm{~kg} / \mathrm{m}^{3}$. Essa característica do produto importado tem forte impacto na qualidade, uma vez que se reflete em um aumento do consumo.

Outro aspecto de qualidade importante e que possui influência no desempenho do produto é a octanagem. As gasolinas importadas apresentam MON acima de 82 e RON típico entre 91 e 91,5, esta última octanagem em geral mais baixa do que das gasolinas produzidas no Brasil.

A partir desse cenário, torna-se importante avaliar o desempenho e consumo de combustível de diferentes gasolinas em motores e veículos com diferentes tecnologias de injeção de combustível. Foram realizados ensaios em banco de provas de motor para avaliação de potência e consumos específicos de combustível mássico e volumétrico, em plena carga e carga parcial, e ensaios de retomada de velocidade e autonomia em dinamômetro de chassi, usando duas diferentes gasolinas $\mathrm{C}$ com $25 \% \mathrm{v} / \mathrm{v}$ de etanol anidro. A base de uma destas gasolinas foi uma gasolina A importada, enquanto a outra foi produzida pela Petrobras. Também foram realizados ensaios de retomada de velocidade em dinamômetro de chassi com veículos de diferentes níveis tecnológicos utilizando duas gasolinas $\mathrm{C}$ com $27 \%$ v/v de etanol anidro, sendo uma delas formulada a partir da mesma gasolina A importada.

\section{METODOLOGIAS}

\subsection{ENSAIOS EM BANCO DE PROVAS DE MOTOR}

A fim de avaliar o impacto da mudança do combustível em motores com diferentes tecnologias de injeção de combustível, foram selecionados dois motores para realização dos ensaios em banco de provas de motor, um com injeção direta de combustível no cilindro (GDI - gasoline direct injection), turbinado 1.0L, e outro com injeção no coletor de admissão (PFI - port fuel injection), aspirado 1.4L.

\subsubsection{Motor GDI Turbo 1.OL Flexfuel}

Foi utilizado um motor GDI turbo 1.0L, montado no banco de provas conforme mostrado na figura 1. Trata-se de um motor de tecnologia avançada, cujas características técnicas principais encontram-se na tabela 1 .

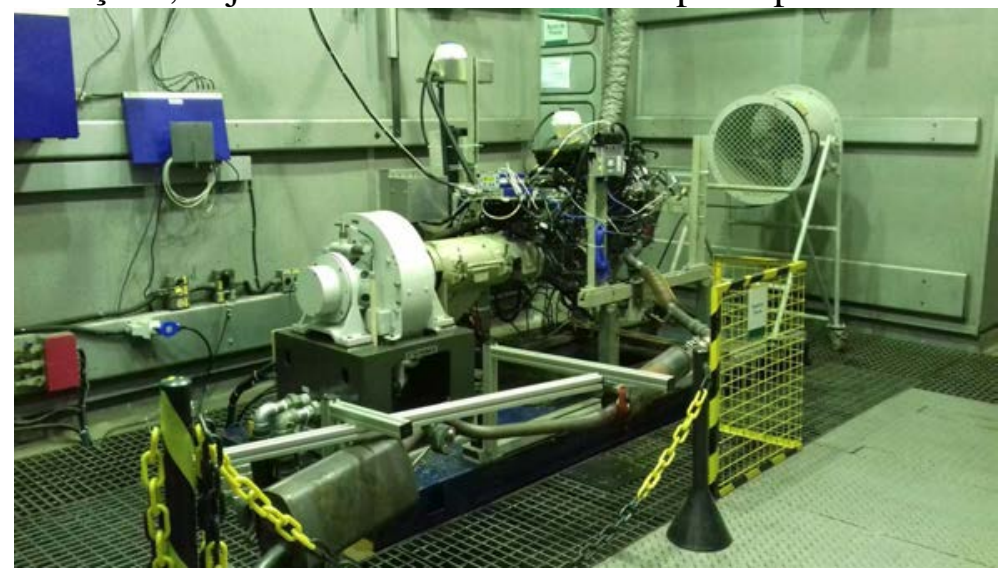

Fig. 1 - Motor GDI turbo 1.0L flexfuel montado no banco de provas. 
Tabela 1 - Principais características do motor GDI turbo 1.0L flexfuel.

\begin{tabular}{|l|l|}
\hline Número de cilindros & 3 em linha \\
\hline Diâmetro x Curso & 74,5 x 76,4 mm \\
\hline $\begin{array}{l}\text { Deslocamento } \\
\text { volumétrico total }\end{array}$ & $0,999 \mathrm{~L}$ \\
\hline Relação de compressão & $10,50: 1$ \\
\hline $\begin{array}{l}\text { Alimentação de } \\
\text { combustível }\end{array}$ & Injeção direta com turbo (GDI turbo), flexfuel. \\
\hline $\begin{array}{l}\text { Potência máxima } \\
\text { (ABNT) }\end{array}$ & $\begin{array}{l}77 \mathrm{~kW} \text { @ 5000 rpm (etanol hidratado) } \\
74 \mathrm{~kW} \text { @ 5000 rpm (gasolina E22) }\end{array}$ \\
\hline Torque máximo (ABNT) & $\begin{array}{l}165 \mathrm{Nm} \text { @ } 1500 \text { rpm } \\
\text { (etanol hidratado e gasolina E22) }\end{array}$ \\
\hline $\begin{array}{l}\text { No de válvulas por } \\
\text { cilindro }\end{array}$ & 4 válvulas por cilindro (duplo comando variável, no cabeçote) \\
\hline
\end{tabular}

Este motor flex possui injeção direta de combustível no cilindro (GDI gasoline direct injection) e turboalimentação, no conceito downsizing, além de possuir vários dispositivos tecnológicos, como comando de válvulas variável, sensor de etanol, entre outros, que contribuem para aumento de eficiência e redução de emissões de poluentes.

Foram realizadas curvas de potência em plena carga, com base na norma ABNT NBR 1585[2] e também ensaiadas condições de carga parcial, com torque constante de $60 \mathrm{Nm}$ (cerca de $35 \%$ do torque máximo do motor), no intervalo de rotações de 1000 a $3000 \mathrm{rpm}$. Os ensaios em carga parcial têm por objetivo representar condições do motor mais próximas do uso urbano. Os parâmetros de operação do motor utilizados para efeito de comparação entre os combustíveis foram potência corrigida, consumo específico mássico e consumo específico volumétrico. Os resultados são apresentados como médias de pelo menos três ensaios em cada condição, com cada combustível. Na comparação estatística dos resultados, foi utilizada a técnica de análise de variância (ANOVA), com nível de significância de 95\%.

\subsubsection{Motor PFI Aspirado 1.4L}

Este segundo motor foi escolhido para ampliar as avaliações, incluindo a tecnologia de injeção de combustível no coletor de admissão, no pórtico das válvulas (PFI - port fuel injection), com boa representatividade tecnológica de mercado. Além disso, o CENPES possui um veículo equipado com o mesmo motor, o que permitiu a realização de ensaios também em dinamômetro de chassi para efeito de comparação dos resultados. Na figura 2 é apresentado o motor montado no banco de provas e na tabela 2 estão suas características técnicas principais. 


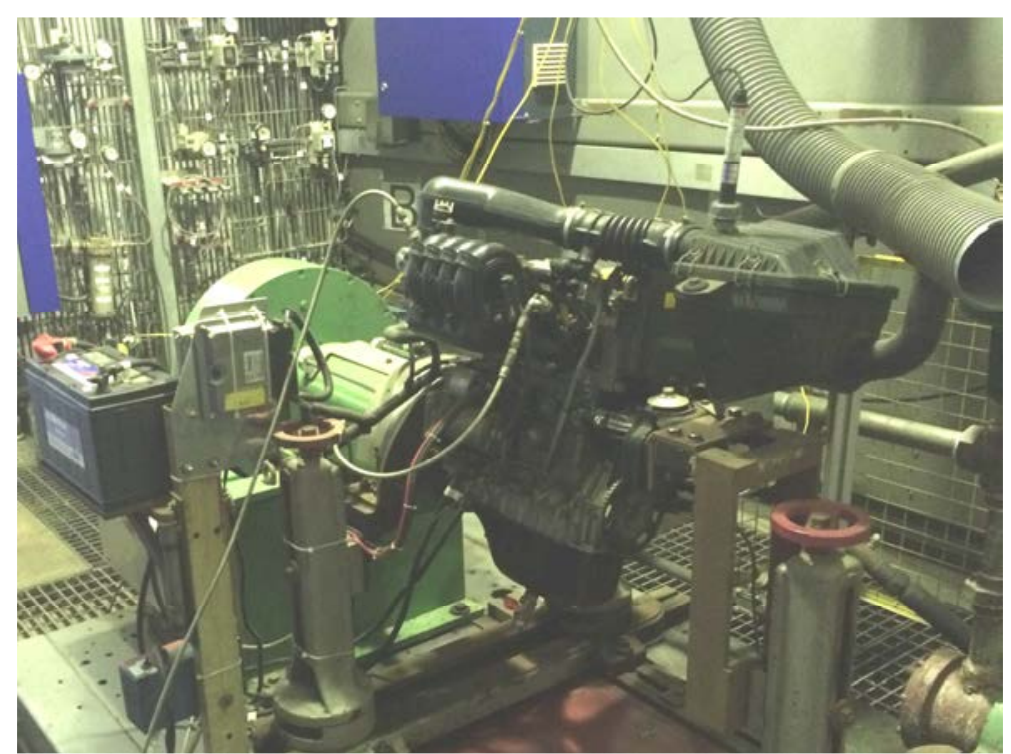

Fig. 3 - Motor PFI aspirado 1.4L montado no banco de provas.

Tabela 2 - Principais características do motor PFI aspirado 1.4L.

\begin{tabular}{|l|l|}
\hline Número de cilindros & 4 em linha \\
\hline Diâmetro x Curso & 72,0 x 84,0 mm \\
\hline $\begin{array}{l}\text { Deslocamento } \\
\text { volumétrico total }\end{array}$ & $1,368 \mathrm{~L}$ \\
\hline Relação de compressão & $10,35: 1$ \\
\hline $\begin{array}{l}\text { Alimentação de } \\
\text { combustível }\end{array}$ & Injeção no pórtico das válvulas, aspirado (PFI aspirado) \\
\hline $\begin{array}{l}\text { Potência máxima } \\
\text { (ABNT) }\end{array}$ & $\begin{array}{l}58,8 \mathrm{~kW} @ 5500 \mathrm{rpm} \text { (gasolina E22) } \\
59,6 \mathrm{~kW} \text { @ 5500 rpm (etanol hidratado) }\end{array}$ \\
\hline Torque máximo (ABNT) & $\begin{array}{l}126 \mathrm{Nm} \text { @ 3500 rpm (gasolina E22) } \\
128 \mathrm{Nm} @ 3500 \mathrm{rpm} \text { (etanol hidratado) }\end{array}$ \\
\hline $\begin{array}{l}\mathrm{N}^{\circ} \text { de válvulas por } \\
\text { cilindro }\end{array}$ & 2 válvulas por cilindro (comando no cabeçote) \\
\hline
\end{tabular}

Da mesma forma que no motor GDI, foram realizadas curvas de potência em plena carga, com base na norma ABNT NBR 1585[2] e também ensaiadas condições de carga parcial, com torque constante de $40 \mathrm{Nm}$ (cerca de $30 \%$ do torque máximo do motor), no intervalo de rotações de 1000 a $3000 \mathrm{rpm}$. Os parâmetros de operação do motor utilizados para efeito de comparação entre os combustíveis foram potência corrigida, consumo específico mássico e consumo específico volumétrico. Os resultados são apresentados como médias de pelo menos três ensaios em cada condição, com cada combustível. Na comparação estatística dos resultados, também foi utilizada ANOVA, com nível de significância de 95\%.

Cabe notar que os ensaios realizados em banco de provas de motor utilizaram somente as gasolinas E25. A incerteza de medição expandida estimada para os resultados dos ensaios em banco de provas de motor é de $0,6 \%$ [3].

\subsection{ENSAIOS EM DINAMÔMETRO DE CHASSI}

\subsubsection{Ensaios de Autonomia Urbana}


Foram realizados ensaios de autonomia em dinamômetro de chassi com base na norma ABNT NBR 7024[4], utilizando um veículo ano de fabricação 2007, equipado com o mesmo motor 1.4L PFI aspirado descrito na seção 1.1.2. Esses ensaios foram realizados com as gasolinas E25 e optou-se por fazer, com cada combustível, apenas a fase quente do ciclo urbano (veículo já aquecido), conhecida como ensaio Hot505, com duração de 505 segundos. Antes de cada ensaio esgota-se completamente o combustível do sistema de alimentação do veículo e o novo combustível de teste é abastecido. Em seguida, o veículo é conduzido por 30 quilômetros em condições de tráfego urbano, no dinamômetro de chassi ou em pista, para adaptação do sistema de controle eletrônico do motor ao novo combustível e passa por um précondicionamento em dinamômetro de chassi, sendo conduzido o mesmo ensaio Hot505. Após este pré-condicionamento, foram realizados três ensaios Hot505 consecutivos com cada combustível para possibilitar o tratamento estatístico dos resultados (ANOVA, com nível de significância de 95\%).

\subsubsection{Ensaios de Desempenho em Pista}

Com relação ao desempenho, foram realizados ensaios de retomada de velocidade em dinamômetro de chassi nos intervalos de 40 a $80 \mathrm{~km} / \mathrm{h}$, em antepenúltima marcha e 60 a $100 \mathrm{~km} / \mathrm{h}$, em penúltima marcha, utilizando as gasolinas E25 e E27. O procedimento de ensaio adotado busca minimizar a dispersão dos resultados e encontra-se descrito no artigo técnico SAE 201536-0196[5]. Para os ensaios com as gasolinas E25 foram utilizados três veículos equipados com sistema de injeção PFI: veículo 1, ano 2007, motor 2.0L; veículo 2 , ano 2007 , motor $1.4 \mathrm{~L}$ e veículo 3 , ano 2011 , motor $1.0 \mathrm{~L}$. Para os ensaios com as gasolinas E27, o veículo 2 foi substituído pelo veículo 4, ano 2016, motor 1.6L turbo e injeção direta de combustível. Para cada combustível, foram realizadas dez retomadas de velocidade em cada intervalo (40-80 e 60-100), de forma a permitir a comparação estatística dos resultados (ANOVA, com nível de significância de 95\%). Para as gasolinas E27 também foram realizados ensaios de potência em regime permanente e monitoramento de detonação (knocking).

\subsection{COMBUSTÍVEIS DE TESTE}

Conforme mencionado anteriormente, foram ensaiadas quatro gasolinas $\mathrm{C}$, sendo duas gasolinas E25 e duas E27. Foram utilizadas três diferentes gasolinas A, uma delas importada e duas produzidas pela Petrobras. Assim, a gasolina A importada foi utilizada para formular uma gasolina C E25 e uma gasolina C E27. As duas outras gasolinas, uma E25 e uma E27, foram formuladas a partir de duas diferentes gasolinas A produzidas pela Petrobras.

As principais propriedades dos combustíveis são apresentadas na tabela 3. A gasolina A importada foi escolhida por possuir uma massa específica de $685,6 \mathrm{~kg} / \mathrm{m}^{3}$, bem inferior à média das massas específicas das gasolinas produzidas pela Petrobras, que foi de $728,1 \mathrm{~kg} / \mathrm{m}^{3}$ entre janeiro e dezembro de 2017. Observa-se que todos os combustíveis atendem a especificação para a gasolina automotiva, conforme estabelecido na Resolução $\mathrm{n}^{\circ}$ 40/2013 da ANP[6], exceto a gasolina C E25 
formulada a partir da gasolina A importada. Esta gasolina, importada para atender a especificação brasileira de gasolina comum com $27 \% \mathrm{v} / \mathrm{v}$ de etanol anidro, possui IAD de 86,4 e não atende ao limite mínimo da especificação da ANP $(87,0)$ com $25 \% \mathrm{v} / \mathrm{v}$ de etanol anidro.

Tabela 3 - Principais propriedades dos combustíveis com $25 \%$ v/v e $27 \%$ v/v de etanol anidro.

\begin{tabular}{|c|c|c|c|c|c|}
\hline \multirow[b]{2}{*}{ Propriedades } & \multirow{2}{*}{$\begin{array}{l}\text { Métodos } \\
\text { Utilizados }\end{array}$} & \multicolumn{4}{|c|}{ Resultados } \\
\hline & & \begin{tabular}{|l|} 
Petrobras \\
E25 \\
\end{tabular} & \begin{tabular}{|l|} 
Importada \\
E25 \\
\end{tabular} & \begin{tabular}{|l} 
Petrobras \\
E27 \\
\end{tabular} & $\begin{array}{l}\text { Importada } \\
\text { E27 } \\
\end{array}$ \\
\hline $\begin{array}{l}\text { Destilação: } \\
\text { PIE, C } \\
10 \% \text { evaporado, }{ }^{\circ} \mathrm{C} \\
50 \% \text { evaporado, }{ }^{\circ} \mathrm{C} \\
90 \% \text { evaporado, }{ }^{\circ} \mathrm{C} \\
\text { PFE, }{ }^{\circ} \mathrm{C} \\
\text { Resíduo, \%v }\end{array}$ & $\begin{array}{l}\text { ASTM D86 } \\
\text { (automático) }\end{array}$ & $\begin{array}{l}37,1 \\
54,3 \\
70,9 \\
150,1 \\
196,8 \\
1,2 \\
\end{array}$ & \begin{tabular}{|l}
38,7 \\
50,2 \\
61,3 \\
74,8 \\
156,7 \\
0,8 \\
\end{tabular} & $\begin{array}{l}40,6 \\
56,7 \\
70,4 \\
133,3 \\
192,1 \\
1,3 \\
\end{array}$ & $\begin{array}{l}37,4 \\
49,6 \\
61,4 \\
75,1 \\
155,8 \\
0,9 \\
\end{array}$ \\
\hline Massa específica a $20^{\circ} \mathrm{C}, \mathrm{kg} / \mathrm{m}^{3}$ & ASTM D4052 & 743,4 & 710,4 & 738,6 & 713,4 \\
\hline MON & ASTM D2700 & 83,8 & 83,3 & 82,1 & 84,0 \\
\hline RON & ASTM D2699 & 96,4 & 89,5 & 93,0 & 90,2 \\
\hline Pressão de vapor a $37,8^{\circ} \mathrm{C}, \mathrm{kPa}$ & ASTM D5191 & 59,4 & 65,4 & 53,5 & 63,3 \\
\hline $\begin{array}{l}\text { Tipos de Hidrocarbonetos: } \\
\text { Aromáticos, \%v } \\
\text { Olefínicos, \%v }\end{array}$ & $\begin{array}{l}\text { CG } \\
\text { N } 2377 \\
\end{array}$ & $\begin{array}{l}14,0 \\
16,8 \\
\end{array}$ & $\begin{array}{l}3,9 \\
0,7 \\
\end{array}$ & \begin{tabular}{|l}
9,9 \\
11,2 \\
\end{tabular} & $\begin{array}{l}3,9 \\
3,2 \\
\end{array}$ \\
\hline Poder calorífico bruto, $\mathrm{MJ} / \mathrm{Kg}$ & ASTM D4809 & 41,850 & 42,491 & 41,548 & 42,230 \\
\hline $\mathrm{RAC}_{\text {est. }}$ & Calculado & 13,11 & 13,48 & 12,92 & 12,82 \\
\hline
\end{tabular}

() Resultados obtidos por extrapolação; LII = Límpido e isento de impurezas.

\section{RESULTADOS E DISCUSSÃO}

Os resultados foram divididos em duas seções principais (2.1 e 2.2). A seção 2.1 contempla a comparação das gasolinas E25 enquanto na seção 2.2 são comparadas as gasolinas E27.

Conforme descrito na seção 1 , referente às metodologias adotadas, nos ensaios em banco de provas de motor, o foco foi dado na comparação da potência corrigida em plena carga, além dos consumos específicos mássico e volumétrico de plena carga e carga parcial. Nos ensaios realizados no dinamômetro de chassi, os parâmetros avaliados foram autonomia e retomada de velocidade do veículo. Para as gasolinas E25 (seção 2.1), primeiro são apresentados os resultados dos ensaios em banco de provas de motor em plena carga e, em seguida, os de carga parcial. Após estes, são apresentados os resultados obtidos no dinamômetro de chassi. Para as gasolinas E27 (seção 2.2) são apresentados somente resultados obtidos no dinamômetro de chassi uma vez que não foram realizados ensaios em banco de provas de motor com estas gasolinas.

\subsection{GASOLINAS E25}

\subsubsection{Resultados dos Ensaios em Banco de Provas de Motor em Plena Carga}

- Potência Corrigida em Plena Carga

As figuras 4 e 5 apresentam as curvas de potência corrigida em plena carga, respectivamente para o motor GDI turbo e PFI aspirado, bem como as 
diferenças máximas e médias de potência corrigida utilizando a gasolina E25 importada e a gasolina E25 produzida pela Petrobras, adotada como referência.

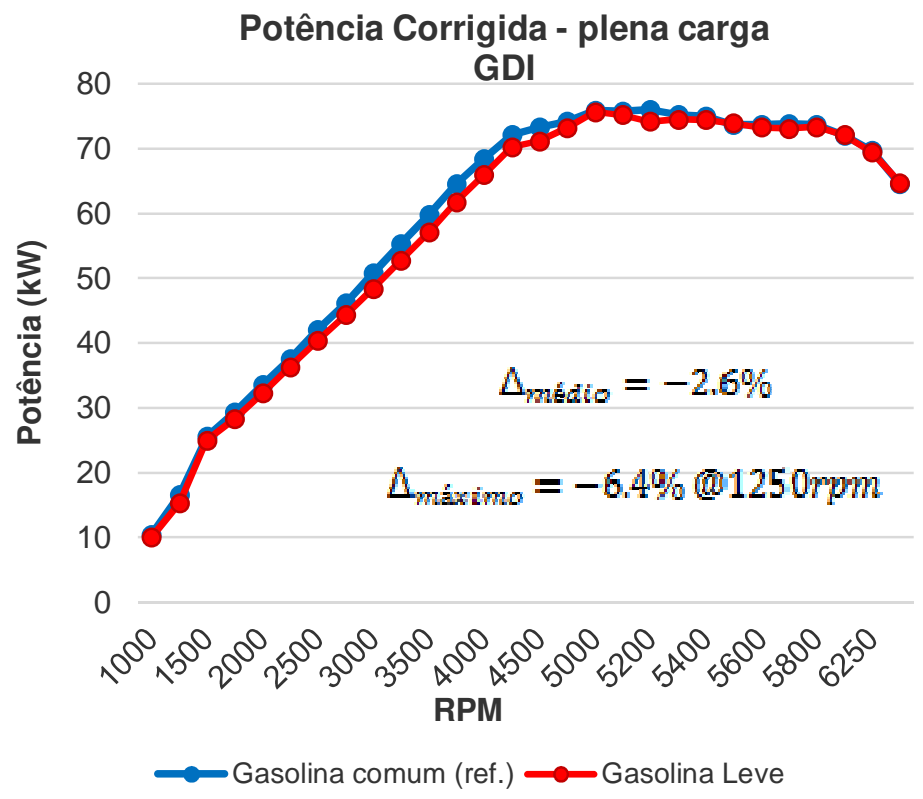

Fig. 4 - Potência corrigida em plena carga no motor GDI (gasolina E25 importada x gasolina E25 produzida pela Petrobras).

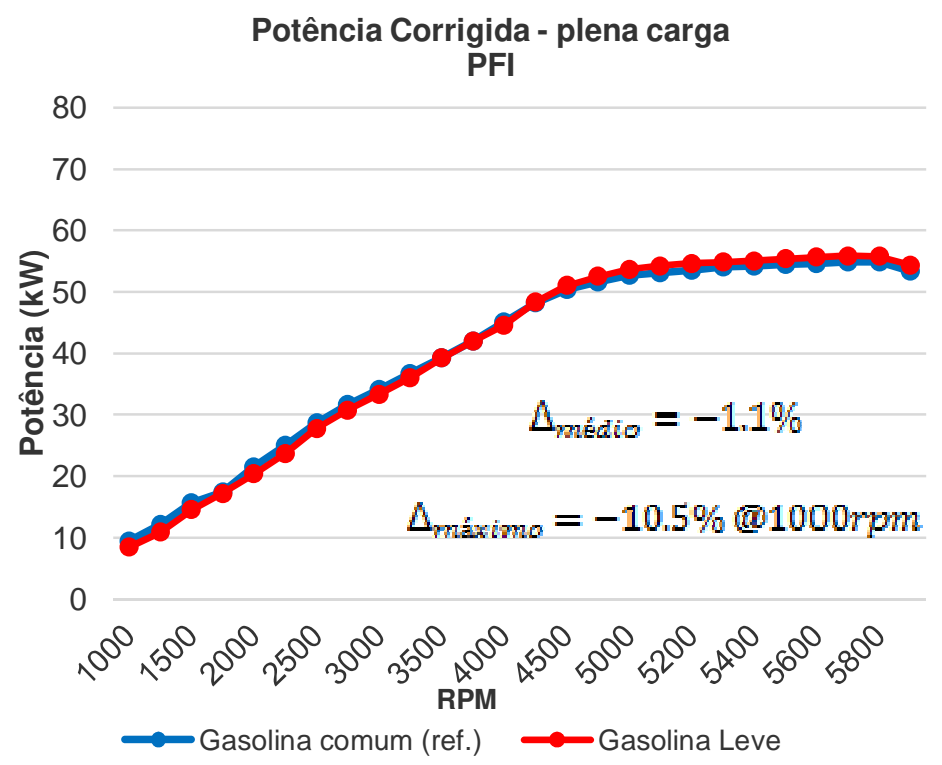

Fig. 5 - Potência corrigida em plena carga no motor PFI (gasolina E25 importada x gasolina E25 produzida pela Petrobras).

Pelas curvas das figuras 4 e 5, nota-se que a gasolina importada apresentou tendência de potência mais baixa em rotações baixas e médias, em ambos os motores (mais evidente no motor GDI). Este comportamento é explicado pelo RON mais baixo da gasolina importada $(89,5)$, quando comparado com o da gasolina produzida pela Petrobras $(96,4)$. Em função do RON mais baixo, as 
ECUs (engine control unit) de ambos os motores reduziram o avanço de ignição para proteger o motor contra a ocorrência de detonação (knocking).

\section{- Consumo Específico Mássico em Plena Carga}

As figuras 6 e 7 apresentam as curvas de consumo específico mássico em plena carga, respectivamente para o motor GDI turbo e PFI aspirado, bem como as diferenças máximas e médias de consumo específico mássico utilizando as gasolinas E25 importada e produzida pela Petrobras. Pelas curvas das figuras 6 e 7, nota-se que a gasolina importada apresentou tendência de maior consumo específico mássico em plena carga, até 4500 rpm, no caso do motor GDI turbo e até $3000 \mathrm{rpm}$, no caso do motor PFI aspirado. Este comportamento é explicado pelas potências mais baixas desenvolvidas pela gasolina leve importada nestas faixas de rotações, em função do seu RON mais baixo. Em rotações mais elevadas, para ambos os motores, há tendência de menor consumo da gasolina importada, devido a sua maior relação ar-combustível estequiométrica (RACest., ver tabela 3), associado ao fato de que o lambda da mistura (razão entre a relação arcombustível real e a estequiométrica) permaneceu praticamente constante com ambos os combustíveis.

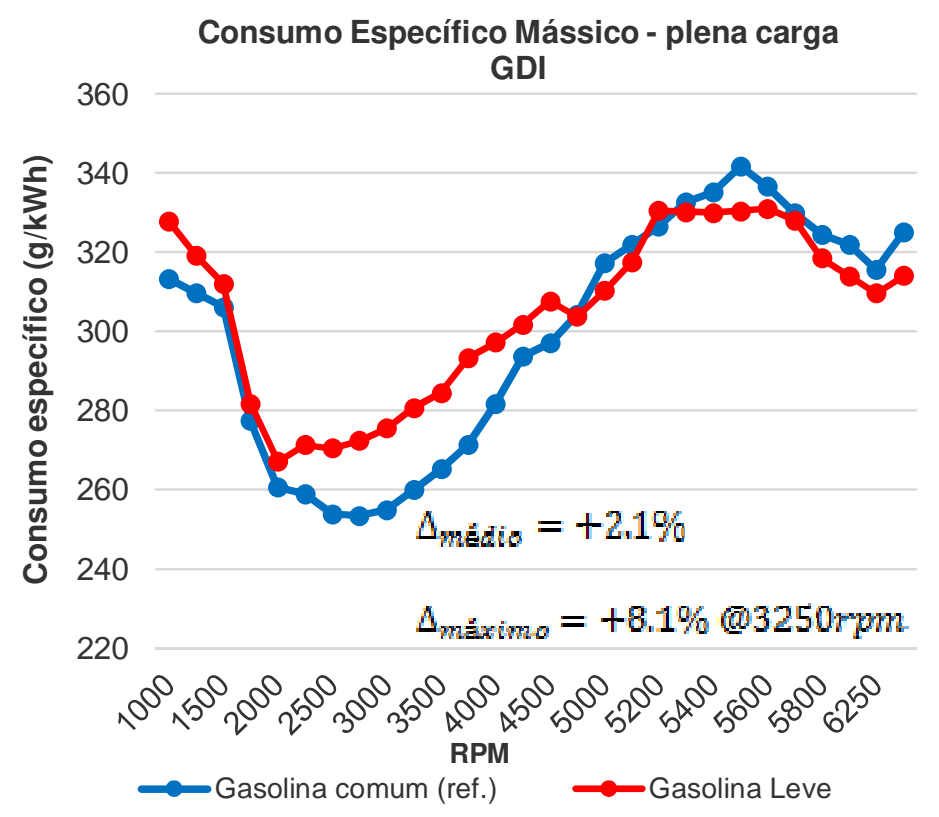

Fig. 6 - Consumo específico mássico em plena carga no motor GDI (gasolina E25 importada x gasolina E25 produzida pela Petrobras). 


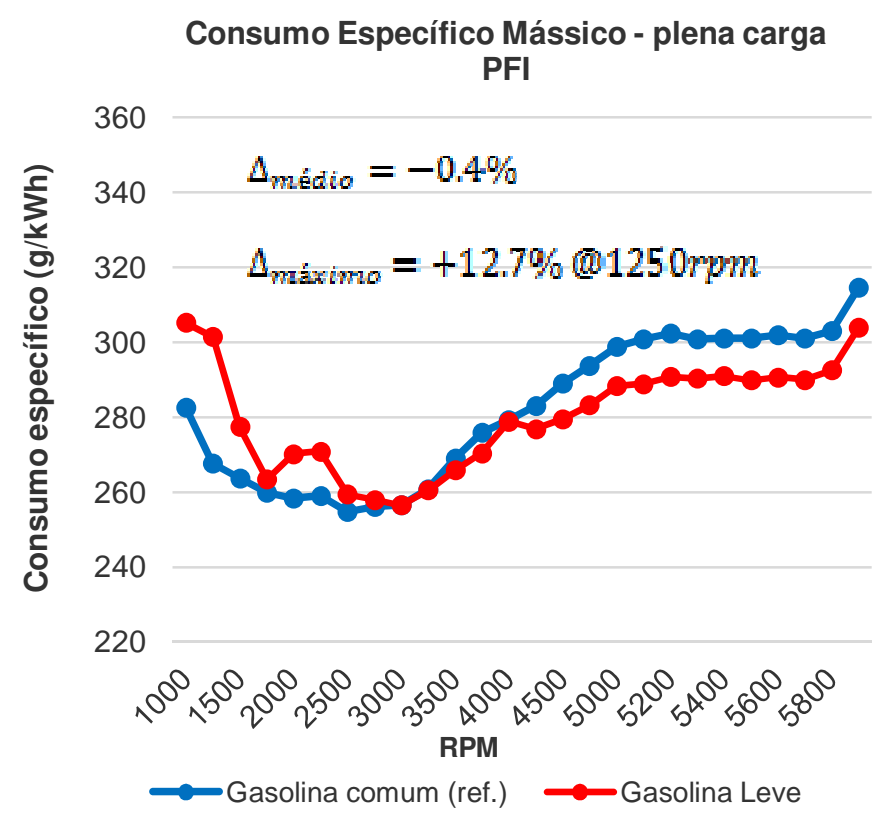

Fig. 7 - Consumo específico mássico em plena carga no motor PFI (gasolina E25 importada x gasolina E25 produzida pela Petrobras).

- Consumo Específico Volumétrico em Plena Carga

As figuras 8 e 9 apresentam as curvas de consumo específico volumétrico em plena carga, respectivamente para o motor GDI turbo e PFI aspirado, bem como as diferenças máximas e médias de consumo específico volumétrico utilizando as gasolinas E25 importada e produzida pela Petrobras.

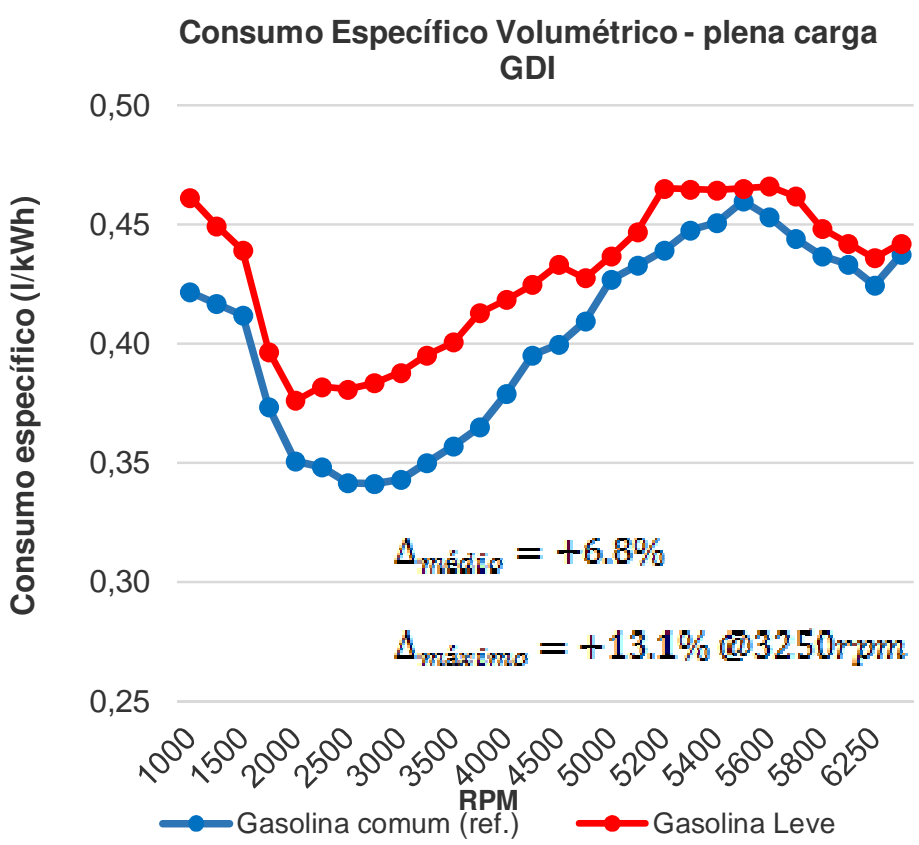

Fig. 8 - Consumo específico volumétrico em plena carga no motor GDI (gasolina E25 importada x gasolina E25 produzida pela Petrobras). 


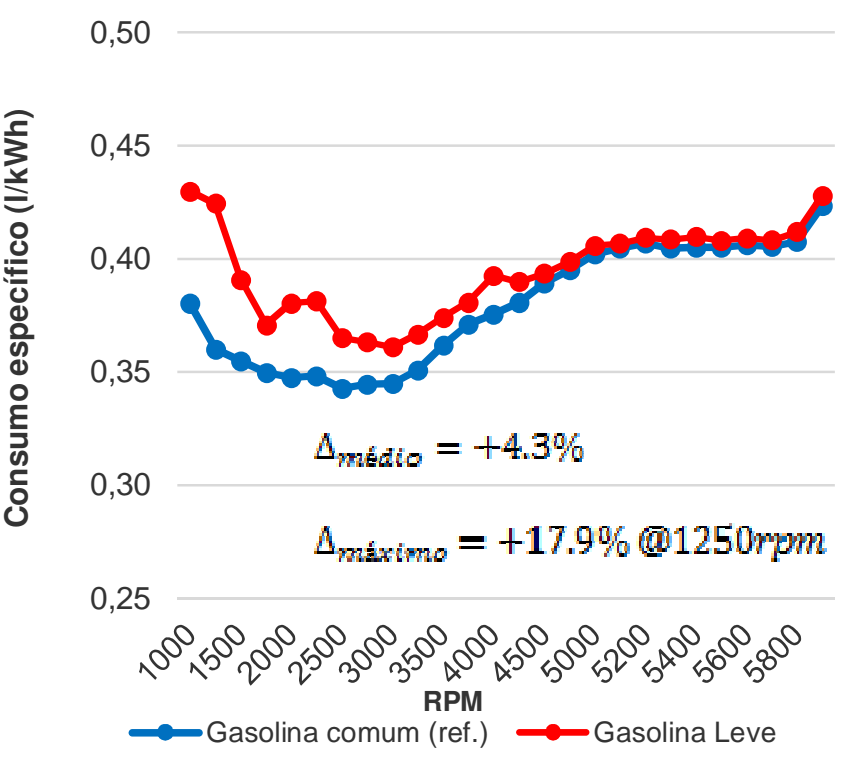

Fig. 9 - Consumo específico volumétrico em plena carga no motor PFI (gasolina E25 importada x gasolina E25 produzida pela Petrobras).

Pelas curvas das figuras 8 e 9, nota-se que a gasolina importada apresentou tendência de maior consumo específico volumétrico em plena carga, em toda a faixa de rotações de ambos os motores. A menor massa específica da gasolina importada em relação à referência (tabela 3), neste caso, foi responsável pelo aumento do consumo específico volumétrico.

Nota-se que para as três variáveis de interesse avaliadas em plena carga, houve uma tendência do motor GDI apresentar maiores desvios médios entre a gasolina importada em relação à gasolina utilizada como referência.

\subsubsection{Resultados dos Ensaios em Banco de Provas de Motor em Carga Parcial}

\section{- Consumo Específico Mássico em Carga Parcial}

As figuras 10 e 11 apresentam as curvas de consumo específico mássico em carga parcial, respectivamente para o motor GDI turbo e PFI aspirado, utilizando as gasolinas E25 importada e produzida pela Petrobras. Na figura 11, do motor PFI aspirado, observa-se que a gasolina importada apresentou tendência de menor consumo específico mássico, em função de sua maior RACest., uma vez que o lambda de carga parcial é constante e igual a 1,0. A tendência do consumo específico mássico em carga parcial foi semelhante ao observado em plena carga para rotações médias e elevadas (figura 7). No caso do motor GDI turbo (figura 10) não foi possível observar diferenças estatisticamente significativas entre os combustíveis, em função da dispersão destes resultados. 


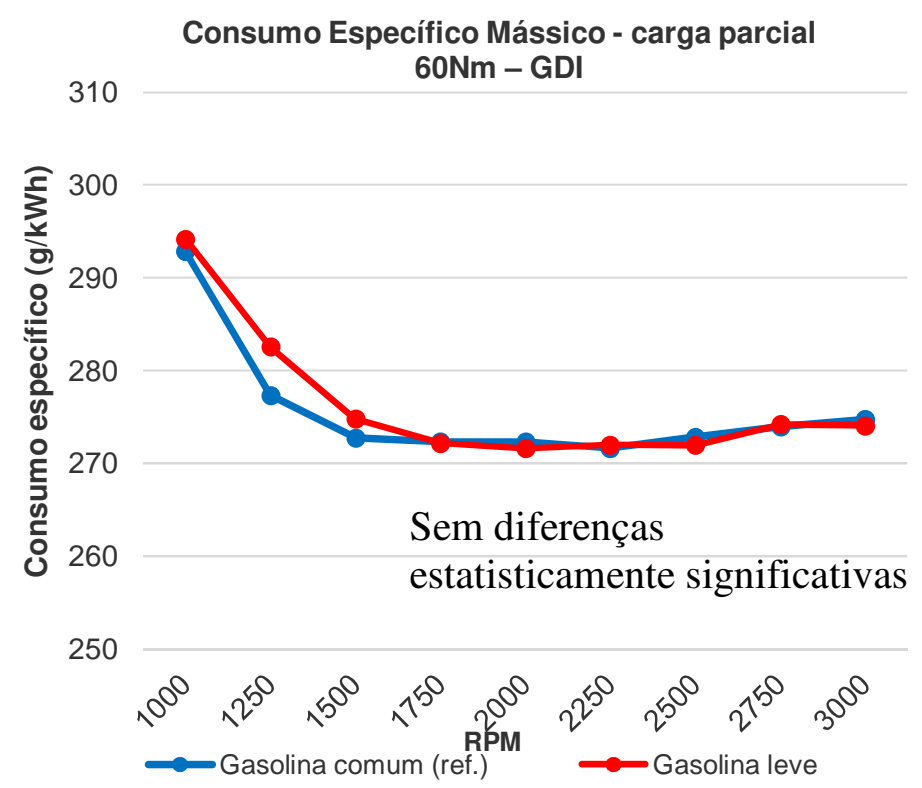

Fig. 10 - Consumo específico mássico em carga parcial no motor GDI (gasolina E25 importada x gasolina E25 produzida pela Petrobras).

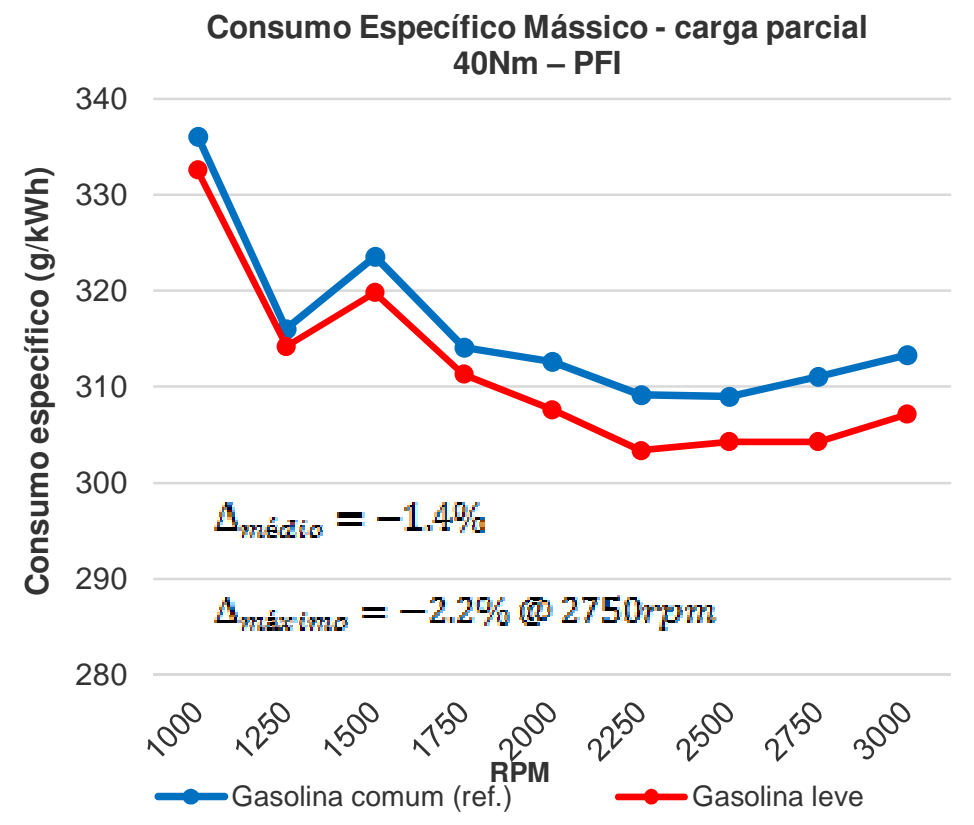

Fig. 11 - Consumo específico mássico em carga parcial no motor PFI (gasolina E25 importada x gasolina E25 produzida pela Petrobras).

\section{- Consumo Específico Volumétrico em Carga Parcial}

As figuras 12 e 13 apresentam as curvas de consumo específico volumétrico em carga parcial, respectivamente para o motor GDI turbo e PFI aspirado, utilizando as gasolinas E25 importada e produzida pela Petrobras. Nestas figuras também são mostradas as diferenças máximas e médias de consumo específico volumétrico em carga parcial encontradas entre os combustíveis. 


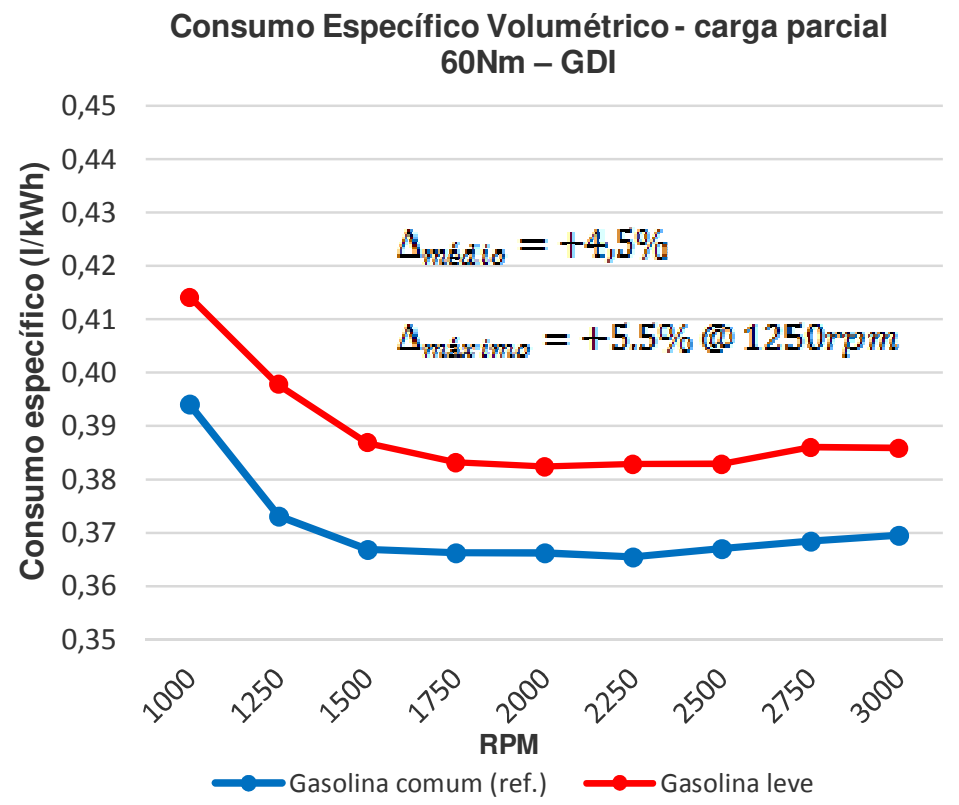

Fig. 12 - Consumo específico volumétrico em carga parcial no motor GDI (gasolina E25 importada x gasolina E25 produzida pela Petrobras).

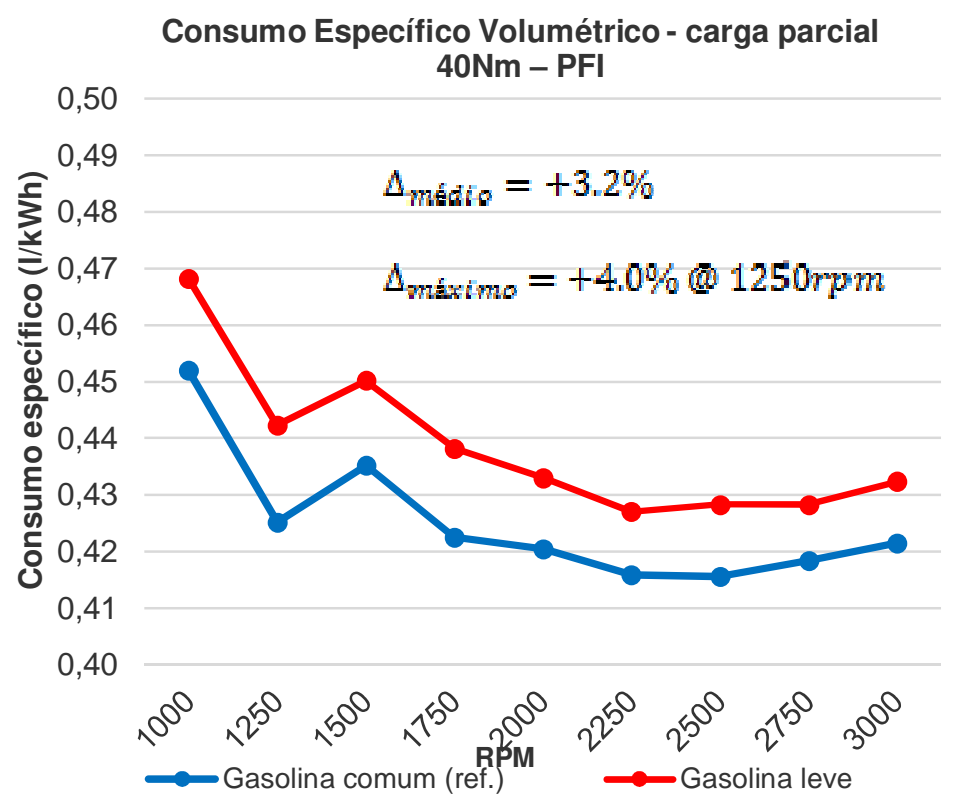

Fig. 13 - Consumo específico volumétrico em carga parcial no motor PFI (gasolina E25 importada x gasolina E25 produzida pela Petrobras).

Nas curvas das figuras 12 e 13 observa-se o maior consumo em base volumétrica da gasolina importada em ambos os motores, o que foi influenciado por sua menor massa específica.

É interessante notar que existe uma tendência geral de inversão de comportamento entre os consumos específicos mássico e volumétrico dos combustíveis, com a gasolina importada apresentando menores consumos mássicos, porém maiores consumos volumétricos. 


\subsubsection{Resultados dos Ensaios em Dinamômetro de Chassi}

\section{- Autonomia}

Na tabela 4 são apresentados os resultados de autonomia em veículo para as gasolinas E25 importada e produzida pela Petrobras. Observa-se que a gasolina importada teve uma autonomia 3,9\% menor que a gasolina produzida pela Petrobras. Este resultado está coerente com os resultados de consumo específico volumétrico de plena carga e carga parcial obtidos em banco de provas de motor, que foram maiores com a gasolina importada, quando comparada à gasolina usada como referência. Este comportamento foi influenciado pela menor massa específica da gasolina importada.

Tabela 4 - Autonomia em dinamômetro de chassi (gasolina E25 importada x gasolina E25 produzida pela Petrobras).

\begin{tabular}{|l|l|l|l|}
\hline Gasolina & Autonomia $(\mathrm{km} / \mathrm{L})$ & $\Delta(\%)$ autonomia & Massa específica $\left(\mathrm{kg} / \mathrm{m}^{3}\right)$ \\
\hline Petrobras & 11,82 & --- & 743,4 \\
\hline Importada & 11,36 & $-3,9 \%$ & 710,4 \\
\hline
\end{tabular}

\section{- Retomada de Velocidade}

A figura 14 apresenta os tempos de retomada de velocidade nos intervalos 40$80 \mathrm{~km} / \mathrm{h}$ e $60-100 \mathrm{~km} / \mathrm{h}$, obtidos com os três veículos citados na seção 1.2.2. Estão ilustradas também as diferenças percentuais dos tempos medidos com a gasolina importada em comparação com a gasolina produzida pela Petrobras. Percentuais negativos representam resultados piores.

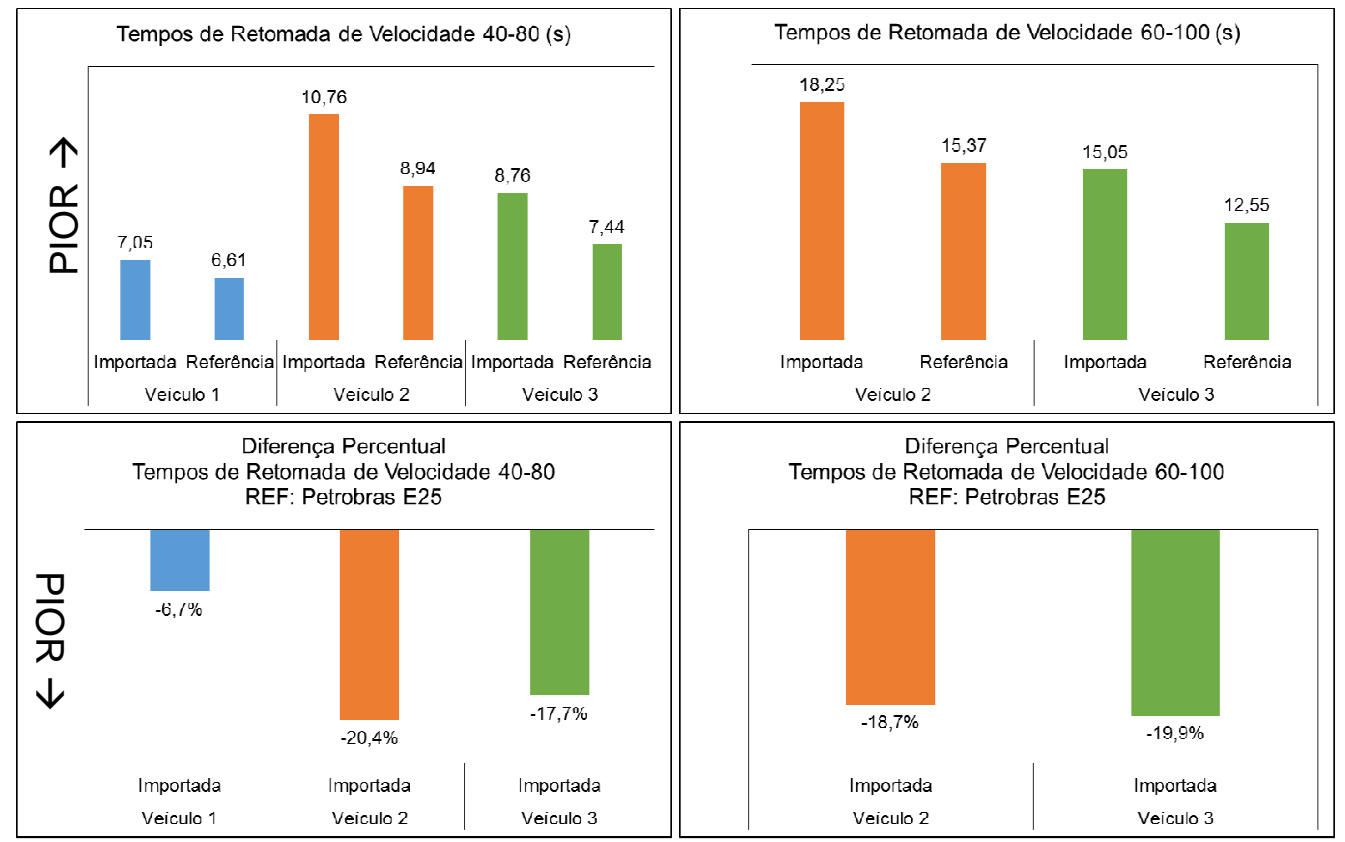

Fig. 14 - Resultados de retomada de velocidade para os veículos 1, 2 e 3 com diferenças percentuais (gasolina E25 importada x gasolina E25 produzida pela Petrobras). 
Verifica-se que os veículos 2 e 3 apresentaram perdas de desempenho significativas utilizando a gasolina importada, com tempos de retomada de velocidade da ordem de $20 \%$ maiores em comparação com a gasolina produzida pela Petrobras. A explicação para resultados tão distintos reside principalmente na diferença de octanagem entre as gasolinas, mas também no mapeamento da ignição dos veículos. $\mathrm{O}$ avanço de ignição médio ao longo das retomadas foi medido, tendo sido encontrados valores entre $5^{\circ} \mathrm{APMS}$ e $8^{\circ} \mathrm{APMS}$ (antes do ponto morto superior) menores com a gasolina importada. Tal diferença causou redução substancial da eficiência com este combustível, refletindo diretamente nos seus maiores tempos de retomada. A estratégia de ignição adotada pelos fabricantes dos veículos inclui a redução drástica do avanço de ignição conforme se reduz a octanagem do combustível para que não ocorra detonação, fenômeno que pode causar danos mecânicos ao motor. É importante ressaltar que a octanagem MON de ambas as gasolinas é semelhante, sendo, portanto, a octanagem RON responsável pela diferença de desempenho observada.

No veículo 1 não foi possível completar os ensaios de retomada de velocidade com a gasolina importada devido à ocorrência de detonação severa. Foram realizadas apenas quatro medições no intervalo $40-80 \mathrm{~km} / \mathrm{h}$, onde foi possível apurar uma piora de desempenho da ordem de $6 \%$ com a gasolina importada em relação à gasolina utilizada como referência. A detonação severa ocorreu devido à octanagem RON mais baixa da gasolina (ver tabela 3 ) e à estratégia de ignição do veículo. A redução de $5^{\circ}$ APMS do avanço com a gasolina importada garantiu um desempenho mais próximo da gasolina de referência, porém não se mostrou eficaz no sentido de evitar o fenômeno da detonação.

\subsection{GASOLINAS E27}

Conforme mencionado anteriormente, para as gasolinas E27 são apresentados somente resultados obtidos no dinamômetro de chassi uma vez que não foram realizados ensaios em banco de provas de motor com estas gasolinas.

\subsubsection{Retomada de Velocidade}

A figura 15 ilustra os tempos de retomada de velocidade, em segundos, no intervalo de 40 a $80 \mathrm{~km} / \mathrm{h}$ e de 60 a $100 \mathrm{~km} / \mathrm{h}$ para os três veículos de teste e as diferenças percentuais estatisticamente significativas encontradas para a gasolina importada (RON90 MON84) em relação à referência produzida pela Petrobras (RON93 MON82). Percentuais negativos representam resultados piores. 


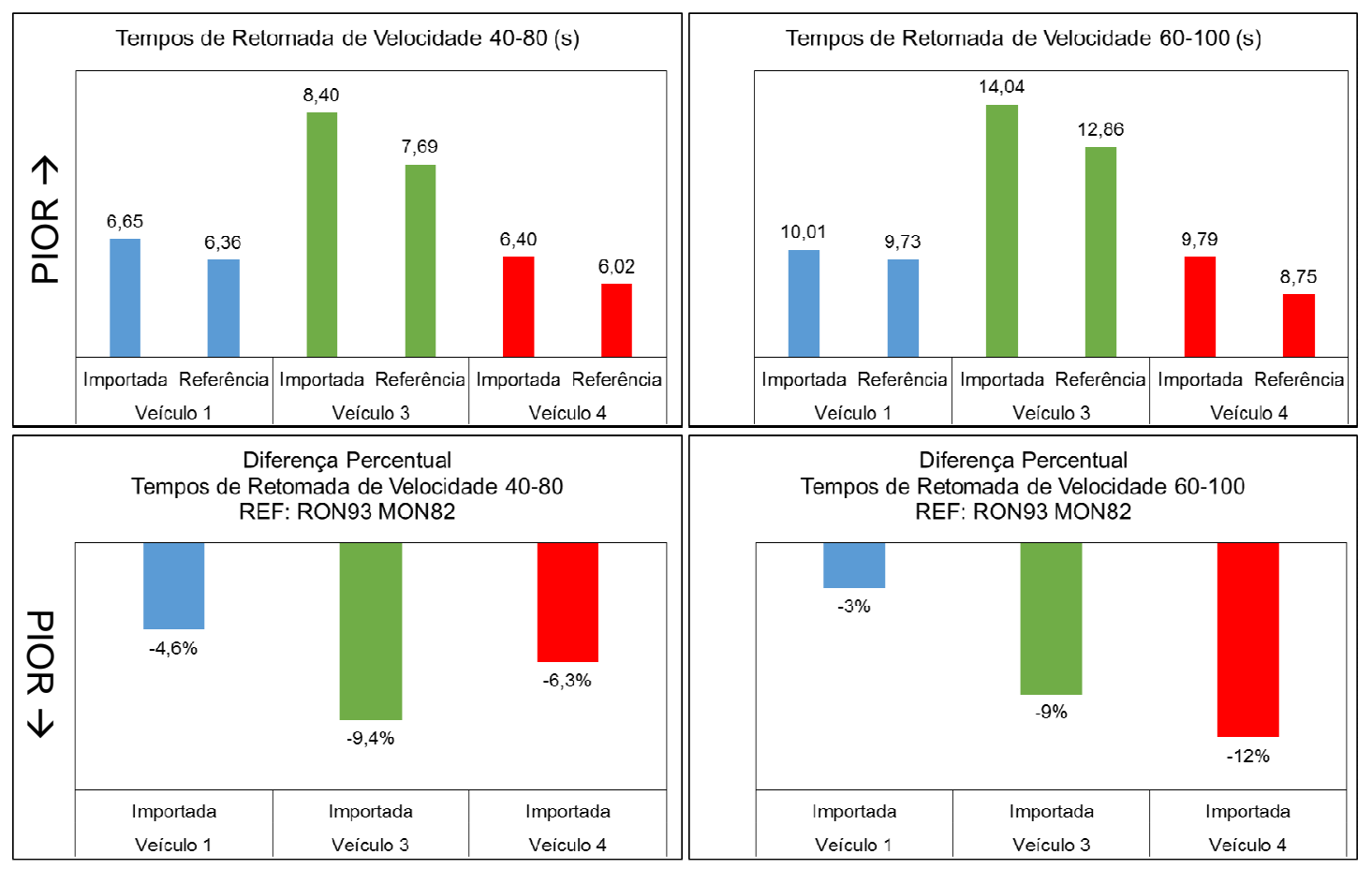

Fig. 15 - Tempos de retomada de velocidade para os veículos 1, 3 e 4 com diferenças percentuais (gasolina E27 importada x gasolina E27 produzida pela Petrobras).

Nota-se que nos três veículos os tempos de retomada de velocidade, em ambos os intervalos, foram maiores utilizando a gasolina importada. As diferenças percentuais detectadas variaram de acordo com o veículo, pois dependem das estratégias de mapeamento da ignição de cada modelo. É importante ressaltar que seus valores são de magnitude tal que poderiam ser detectadas por usuários comuns.

Pelas diferenças medidas podem-se verificar algumas características de mapeamento de ignição dos veículos quando utilizam gasolinas de baixa octanagem. Os maiores percentuais de perda de desempenho com a gasolina importada, observados nos veículos 3 e 4 ( $9 \%$ em média), indicam que a calibração de seus motores permite maior retardo da centelha, o que reduz a eficiência do motor, porém minimiza a ocorrência de detonação e a chance de danos mecânicos. Para o veículo 1 os percentuais de perda de desempenho foram mais discretos (4\% em média), o que é uma indicação de que o seu mapeamento de ignição atua de forma menos robusta em relação ao retardo da centelha quando utiliza gasolinas com octanagem mais baixas. Essa estratégia traz menores perdas de desempenho, porém o motor fica mais exposto à ocorrência de detonação e, consequentemente, a danos mecânicos.

Outra observação importante diz respeito à octanagem MON. O fato da gasolina importada (RON90 MON84) possuir 2 pontos a mais de MON que a gasolina produzida pela Petrobras (RON93 MON82) não foi suficiente para evitar a perda de desempenho ocasionada pela diferença contrária na octanagem RON (3 pontos a menos para a importada). Isso demonstra coerência com outros trabalhos publicados[7, 8], os quais indicam predominância da influência do RON e a baixa relevância do MON para o desempenho e eficiência dos motores mais modernos. 
De maneira complementar, foram realizados ensaios de potência em regime permanente com o objetivo de investigar o comportamento dos veículos no que se refere ao mapeamento de ignição e constatar os motivos das diferenças de desempenho encontradas entre as gasolinas de teste nos ensaios de retomada de velocidade. Durante esses ensaios, além da potência, o ângulo de ignição em relação ao ponto morto superior ( $\left.{ }^{\circ} \mathrm{APMS}\right)$ foi medido em velocidades representativas dos ensaios de retomada (40, 60 e $80 \mathrm{~km} / \mathrm{h}$ a plena carga). Tais medições poderiam ser realizadas durante as retomadas de velocidade. No entanto, as medições em regime permanente apresentam maior estabilidade e precisão para a análise dos resultados. Além disso, torna possível correlacionar tendências de resultados em regimes transientes (retomadas) e permanentes.

Como forma de caracterizar o comportamento ao longo de um intervalo de retomada, e não somente em pontos operacionais específicos, são apresentados, na tabela 5, os valores médios de potência e de avanço de ignição. Estes valores foram calculados para cada veículo a partir dos resultados das velocidades de teste acima mencionadas. São apresentadas também na tabela 5 as diferenças entre as médias obtidas para as duas gasolinas de teste.

Tabela 5 - Valores médios de potência e de avanço de ignição, considerando as diferentes velocidades de teste e as diferenças entre as médias.

\begin{tabular}{|c|c|c|c|c|c|}
\hline \multirow{2}{*}{ Veículo } & \multirow{2}{*}{ Combustível } & \multicolumn{2}{|l|}{ Média } & \multicolumn{2}{|c|}{ Diferença } \\
\hline & & $\mathrm{P}(\mathrm{kW})$ & $\mathrm{A}\left({ }^{\circ} \mathrm{APMS}\right)$ & $\mathrm{P}(\%)$ & $\mathrm{A}\left({ }^{\circ}\right)$ \\
\hline \multirow{2}{*}{1} & Importada & 45,79 & 13,2 & \multirow{2}{*}{$0 \%$} & \multirow{2}{*}{0} \\
\hline & Referência & 45,74 & 13,2 & & \\
\hline \multirow{2}{*}{3} & Importada & 29,69 & 7,5 & \multirow{2}{*}{$-3 \%$} & \multirow{2}{*}{-2} \\
\hline & Referência & 30,57 & 9,5 & & \\
\hline \multirow{2}{*}{4} & Importada & 50,86 & 0,2 & \multirow{2}{*}{$-9 \%$} & \multirow{2}{*}{-2} \\
\hline & Referência & 55,90 & 2,5 & & \\
\hline
\end{tabular}

Observa-se que os veículos 3 e 4 desenvolveram, respectivamente, potências 3\% e $9 \%$ menores com a gasolina importada (RON90 MON84). Isso ocorreu devido ao retardamento médio de 2 graus no ângulo de ignição com esta gasolina, função de sua octanagem RON inferior. Os percentuais de perda de desempenho podem variar de veículo para veículo em função de outros parâmetros, como, por exemplo, a estratégia de injeção de combustível. Porém, o avanço de ignição (consequência direta da octanagem) é, reconhecidamente, aquele que exerce maior influência no desempenho do motor[7, 8].

Em relação ao veículo 1, como consequência da manutenção do avanço de ignição médio, a potência média não se alterou com a gasolina RON90 MON84. No entanto, nas velocidades de $40 \mathrm{~km} / \mathrm{h}$ e $60 \mathrm{~km} / \mathrm{h}$ o veículo desenvolveu potência equivalente ou inferior com a gasolina em questão em comparação com a formulação de referência (RON93 MON82), enquanto que em $80 \mathrm{~km} / \mathrm{h}$ essa tendência se inverteu. Dessa forma, mesmo que a média aritmética tenha apontado uma potência equivalente nesse intervalo de velocidades, o trecho de menores velocidades pode ter exercido maior peso no resultado final, explicando os tempos de retomada maiores medidos para a gasolina importada, porém em percentuais menores do que nos veículos 3 e 4 . 
Além disso, o avanço aplicado no período transiente pode ter sido menor com a gasolina importada, contribuindo para os maiores tempos de retomada.

Outra hipótese, que poderia ser estudada em testes mais extensos, é que para o veículo 1 a relevância da octanagem MON seja maior do que para os demais veículos e, devido aos 2 pontos a mais de MON da gasolina importada (RON90 MON84) em comparação com a formulação da Petrobras (RON93 MON82), as diferenças de desempenho tenham sido menores neste veículo. De qualquer forma, é possível notar que o veículo 1 possui mapeamento de ignição tal que não resulta em perdas de desempenho elevadas, porém o torna mais vulnerável à detonação e a danos mecânicos com gasolinas de baixa octanagem.

\subsubsection{Detonação}

As figuras 16 a 21 ilustram os resultados do processamento dos arquivos de áudio gravados para os três veículos à $40 \mathrm{~km} / \mathrm{h}$ e plena carga no dinamômetro de chassi. Esta condição foi selecionada, pois foi a mais crítica com relação à detonação. A intensidade da detonação foi classificada de acordo com a magnitude da escala adimensional apresentada pelo software de tratamento de áudio: até 0,5 - Traços; entre 0,5 e 1,0 - Leve; entre 1,0 e 2,0 - Média; maior do que 2,0 - Severa. Esta escala foi estabelecida com base em procedimento de detonação audível[9] e buscou correlacionar a magnitude do pico com a intensidade audível da detonação ocorrida nos veículos.

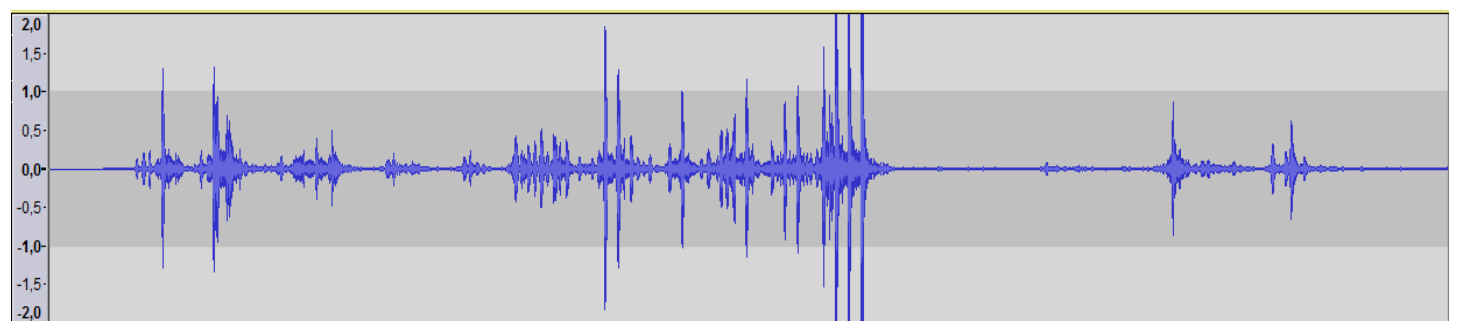

Figura 16 - Arquivo de áudio do veículo 1 com a gasolina RON90 MON84.

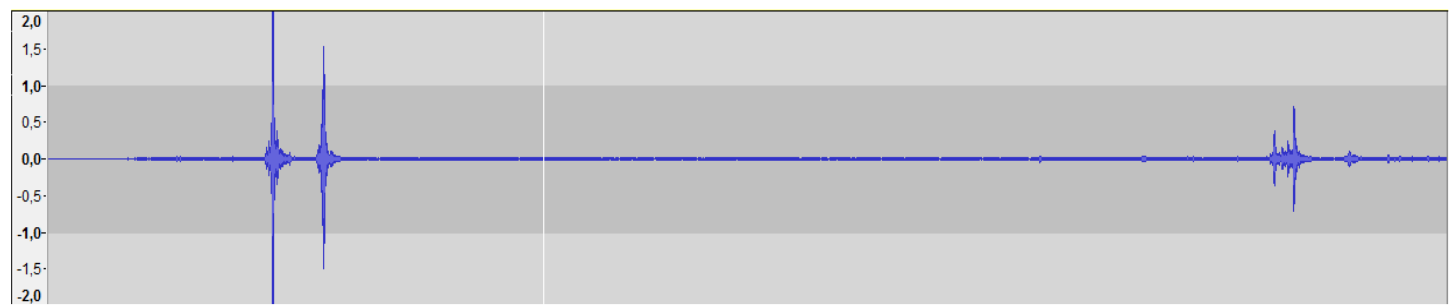

Figura 17 - Arquivo de áudio do veículo 1 com a gasolina RON93 MON82.

Em relação ao veículo 1, verifica-se que a utilização da gasolina importada (RON90 MON84) resultou em diversas ocorrências desde traços até detonações severas. Já para a gasolina produzida pela Petrobras (RON93 MON82) foram observados um pico severo, um pico médio, um pico leve e alguns traços de detonação. A diferença no nível de detonação é bastante clara entre as gasolinas, confirmando o que os resultados de retomada e potência sugeriram sobre a estratégia de mapeamento do veículo. Como visto no item 2.2.1, o retardamento da centelha ocorreu de forma mais discreta, não sendo capaz de evitar eventos de detonações mais intensas. Isso resultou em menores perdas de desempenho, porém o motor opera em condições 
mais expostas a danos mecânicos. É importante ressaltar a ocorrência de detonações severa e média com a gasolina RON93 MON82. O fato de terem sido picos isolados e decrescentes ao longo do ensaio demonstra que, neste nível de octanagem, o mapeamento de ignição foi capaz de reagir e minimizar os eventos de detonação.

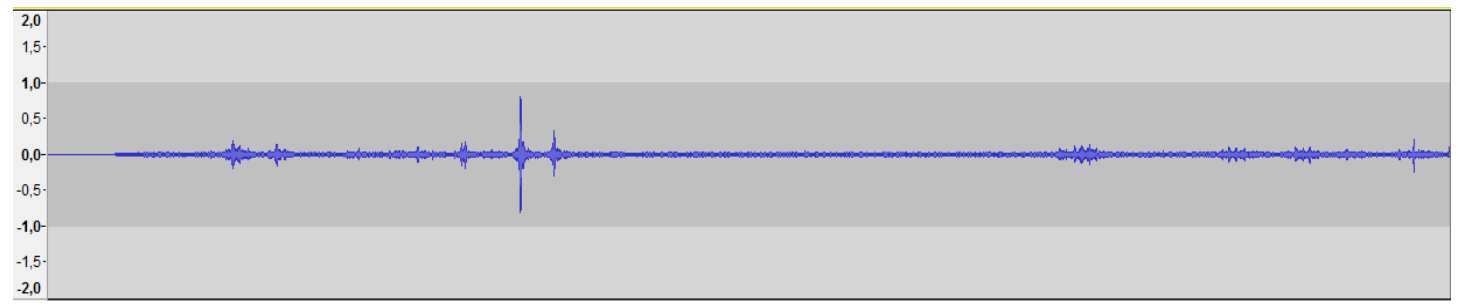

Figura 18 - Arquivo de áudio do veículo 3 com a gasolina RON90 MON84.

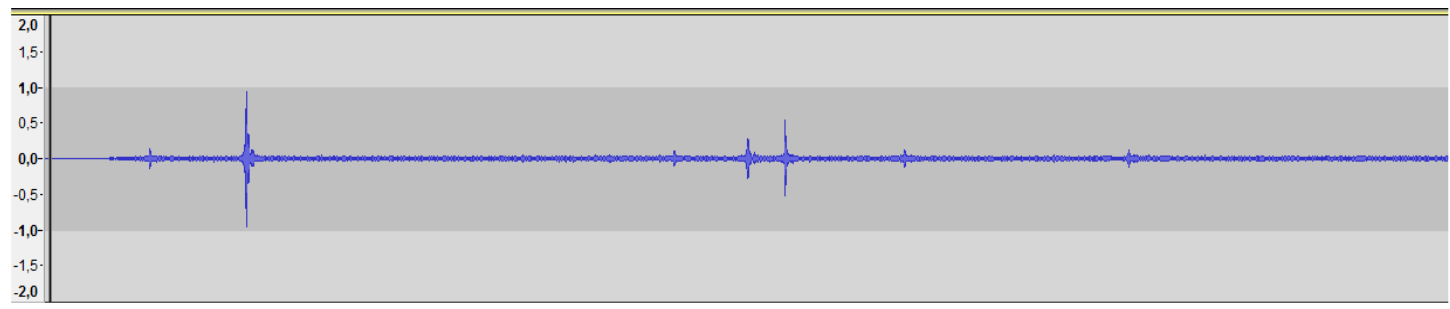

Figura 19 - Arquivo de áudio do veículo 3 com a gasolina RON93 MON82.

Para o veículo 3 nota-se que o nível de detonação foi equivalente para ambos os combustíveis. Ocorreu um pico de detonação leve e um número semelhante de traços de detonação, apesar de haver uma tendência de maiores magnitudes destes traços para gasolina importada (RON90 MON84). Os resultados demonstram que o mapeamento da ignição deste veículo retarda a centelha, com base na informação do sensor de detonação, levando o veículo a operar em um nível semelhante de detonação, independentemente da octanagem da gasolina. Como já visto no item 2.2.1, isso tem como consequência perdas de desempenho maiores quando menores octanagens são utilizadas, porém oferece maior proteção ao motor.

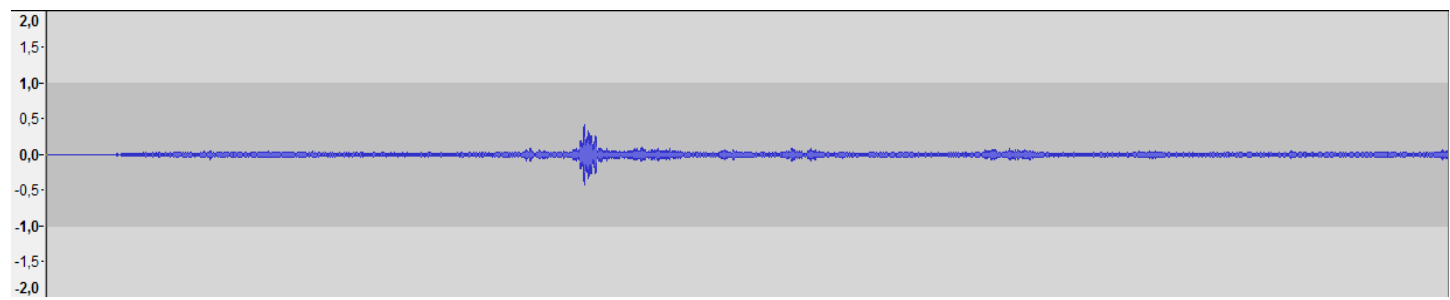

Figura 20 - Arquivo de áudio do veículo 4 com a gasolina RON90 MON84.

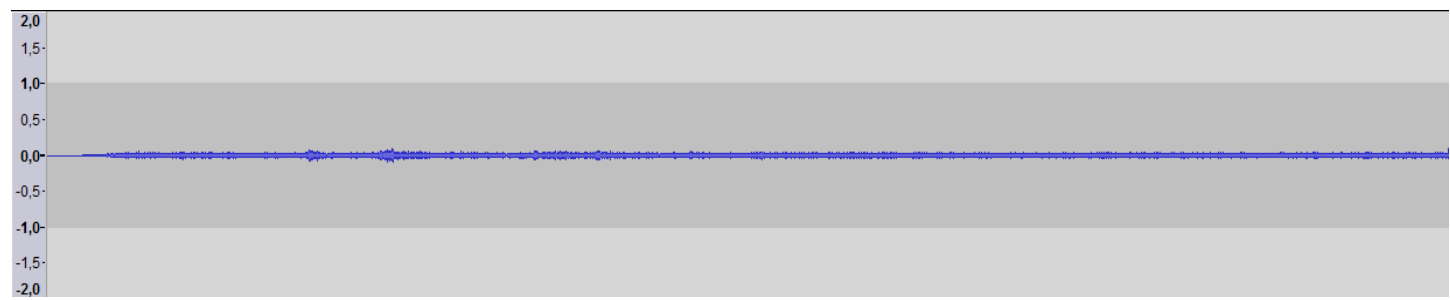

Figura 21 - Arquivo de áudio do veículo 4 com a gasolina RON93 MON82.

O veículo 4 resultou em menor propensão à detonação com a gasolina importada (RON90 MON84). Apenas traços de detonação foram observados. Isso pode ser uma 
explicação para as perdas percentuais de desempenho observadas nas retomadas de velocidade. Com a gasolina produzida pela Petrobras (RON93 MON82) não foram detectadas detonações, conforme o critério estabelecido para o ensaio. Os resultados demonstram que a estratégia de mapeamento de ignição do veículo privilegia a proteção a danos no motor em detrimento do seu desempenho.

\section{CONCLUSÃO}

Para as gasolinas E25, nos resultados dos ensaios em banco de provas de motor a gasolina importada apresentou potências de plena carga em média 2,6\% e 1,1\% mais baixas que a gasolina produzida pela Petrobras, respectivamente nos motores GDI e PFI, principalmente em baixas e médias rotações, em função do seu baixo RON (89,5 contra 96,4 da gasolina de referência).

Com relação ao consumo específico de combustível, observaram-se tendências diferentes entre os consumos mássico e volumétrico. No consumo mássico, em geral, a influencia preponderante foi da relação ar-combustível estequiométrica (RACest.) do combustível. Assim, a gasolina importada, que possui maior RACest., apresentou tendência de redução do consumo em relação à gasolina produzida pela Petrobras, com exceção das condições de baixas e médias rotações, que mostrou aumento do consumo mássico, influenciado pelo seu RON baixo (redução de potência), em ambos os motores. No caso do consumo específico volumétrico, a gasolina importada, com massa específica mais baixa, apresentou tendência de consumo mais elevado em relação à gasolina produzida pela Petrobras. A elevação média do consumo específico volumétrico foi de $6,8 \%$ e $4,3 \%$, em plena carga, e de $4,5 \%$ e $3,2 \%$, em carga parcial, respectivamente nos motores GDI e PFI.

O resultado de autonomia em dinamômetro de chassi, expresso em $\mathrm{km} / \mathrm{L}$, mostrou tendência coerente com os resultados de consumo específico volumétrico obtidos no motor, ou seja, a gasolina importada, de menor massa específica, que apresentou, em geral, maior consumo específico volumétrico, proporcionou menores autonomias no veículo. A redução de autonomia foi de 3,9\% em relação à gasolina produzida pela Petrobras.

Com relação ao desempenho em veículos, foram observadas perdas significativas nos tempos de retomada de velocidade, da ordem de $20 \%$, com os veículos 2 e 3 usando a gasolina importada em relação à gasolina produzida pela Petrobras. No veículo 1 foram apuradas perdas menores, de $6,6 \%$. No entanto, para este veículo foi constatada ocorrência de detonação, o que impediu que os ensaios fossem completados, devido ao risco de danificar o motor do veículo. É importante ressaltar que a diferença de desempenho verificada ocorreu, principalmente, devido a menor octanagem RON da gasolina importada, já que a octanagem MON de ambas as gasolinas é semelhante. O mapeamento da ignição também se mostrou bastante influente, uma vez que define a estratégia de proteção do motor, no caso de combustíveis com octanagens mais baixas.

Os resultados de desempenho obtidos no presente trabalho mostram coerência entre condições permanentes (rotação e carga constantes), ensaiadas em motores, e transientes (acelerações), ensaiadas em veículos, sendo que as diferenças entre os combustíveis foram mais expressivas 
na condição transiente. Uma hipótese para esse comportamento é que a condição transiente seja mais fortemente influenciada pela octanagem RON do que a condição permanente.

Para as gasolinas E27 foram realizados ensaios somente em dinamômetro de chassi. Nos ensaios de desempenho, os tempos de retomada de velocidade, nos três veículos testados, em ambos os intervalos (40 a $80 \mathrm{~km} / \mathrm{h}$ e 60 a $100 \mathrm{~km} / \mathrm{h}$ ), foram maiores utilizando a gasolina importada (RON90 MON84). As perdas de desempenho variaram entre 3\% e $12 \%$ de acordo com o veículo, pois dependem das estratégias de mapeamento da ignição. É importante ressaltar que as perdas possuem magnitude passível de percepção pelos usuários comuns.

O fato da gasolina importada (RON90 MON84) possuir 2 pontos a mais de MON que a gasolina produzida pela Petrobras (RON93 MON82) não foi suficiente para evitar a perda de desempenho ocasionada pela diferença contrária na octanagem RON (3 pontos a menos) nos três veículos de teste. Isso demonstra coerência com outros trabalhos publicados, no que se refere à baixa relevância do MON no desempenho dos veículos mais modernos. Os ensaios de potência e detonação esclareceram os resultados obtidos nas retomadas de velocidade. Demonstrou-se que a estratégia de mapeamento da ignição é determinante para o comportamento do veículo em plena carga com gasolinas de octanagens mais baixas. Verificou-se que os veículos 3 e 4 privilegiam a proteção ao motor em detrimento do desempenho, enquanto o veículo 1 compromete o desempenho em menor escala, porém com maior risco de danos ao motor devido à ocorrência de detonação.

\section{REFERÊNCIAS}

[1] ANP - AGÊNCIA NACIONAL DO PETRÓLEO, GÁS NATURAL E BIOCOMBUSTÍVEIS. Importações e Exportações (metros cúbicos). Disponível em: http://www.anp.gov.br/dados-estatisticos. Acesso em: 30 abr. 2018.

[2] ABNT - ASSOCIAÇÃO BRASILEIRA DE NORMAS TÉCNICAS. NBR ISO 1585: Veículos rodoviários - Código de ensaio de motores - Potência líquida efetiva. Rio de Janeiro, 1996.

[3] MACHADO, G.B., Metodologias para Desenvolvimento de Combustíveis e Determinação da Velocidade de Propagação de Chama em Motores de Ignição por Centelha, Tese de Doutorado, PUC-Rio - Departamento de Engenharia Mecânica, Rio de Janeiro, Brasil, 2012.

[4] ABNT - ASSOCIAÇÃO BRASILEIRA DE NORMAS TÉCNICAS. NBR 7024: Veículos rodoviários automotores leves - Medição do consumo de combustível - Método de ensaio. Rio de Janeiro, 2010.

[5] VILLELA, A.C.S.; BOTERO, S.W.; CARVALHO, R.N.; Vehicle Speed Recovery Test Methodologies on Chassis Dynamometer and their Correlation with Track Test Results, SAE Technical Paper 2015-36-0196, 24th SAE Brazil International Congress, 2015.

[6] ANP- AGÊNCIA NACIONAL DO PETRÓLEO, GÁS NATURAL E BIOCOMBUSTÍVEIS, Resolução ANP n 40/2013, publicada no DOU em outubro de 2013.

[7] KALGHATGI, G.T., Fuel Anti-Knock Quality - Part I. Engine Studies, SAE 2001-013584, San Antonio, Texas, 2001.

[8] KALGHATGI, G.T., Fuel Anti-Knock Quality- Part II. Vehicle Studies - How Relevant is Motor Octane Number (MON) in Modern Engines? SAE 2001-01-3585, San Antonio, Texas, 2001.

[9] CT DIPROD 10/91 - Procedimento de Teste de Campo de Detonação Audível em Veículos Equipados com Motores do Ciclo Otto. 